\title{
Mathematical modelling of the drying process of sugar beet pulp with macro and microelement additions in order to improve the feed quality
}

\author{
Elena Mihaela Nagy ${ }^{*}$, Constantin Coța ${ }^{1}$, Zoltan Gyorgy $^{1}$, and Teodora Deac ${ }^{2}$ \\ ${ }^{1}$ INMA Bucharest, Branch Cluj-Napoca, 400436, 59 Al. Vaida Voievod Str., Cluj Napoca, Romania \\ ${ }^{2}$ Technical University of Cluj-Napoca, Faculty of Mechanical Engineering, 400641, 103-105 Muncii \\ Bdul, Romania
}

\begin{abstract}
In this paper a kinetic study is performed on the drying process of beet pulp with additions of macro-elements $\left(\mathrm{Ca}^{2+}, \mathrm{Mg}^{2+}, \mathrm{PO}_{4}{ }^{2+}\right)$ from hydrated lime, hydrated dolomite lime, phosphoric acid and microelements $\left(\mathrm{Co}^{2+}, \mathrm{Zn}^{2+}, \mathrm{Fe}^{2+}, \mathrm{Mn}^{2+}\right)$, with the purpose of obtaining premixes with substantially improved value for animal feed. The experimental measurements made served to elaborate the mathematical model by means of which the speed with which the drying process is carried out is described, thus being able to calculate the stationing time of the material in the dryer. The equations for calculating the stationary time of the material in the dryer can be used for designing dryers (sizing them).
\end{abstract}

\section{Introduction}

The technological process of sugar production from beet processing has as a by-product a fibrous material (pulp) which represents about $5 \%$ from the processed quantity of beet $[1$, 2]. This pulp could be used as valuable fodder with high energy potential and increased efficiency in feeding animals, especially ruminants: milk cows of high productivity, bulls and rams that are intensively fattened.

From the point of view of energy, the nutritional value of the sugar beet pulp is comparable with that of good quality hay with the mention that its assimilation is much easier and of high efficiency that can reach $90-95 \%$ [3].

From a chemical point of view the pulp resulting from the technological process of sugar production is a macromolecular complex of the beet cellular membrane, composed of protopectin which under the influence of pectolytic enzymes from the digestive system is easily hydrolysed both in an acidic and alkaline medium in the intestinal tract of animals.

As a result of the process of hydrolysis the protopectins are transformed into pectinic acid and polypectins, products of low molecular mass, water soluble, that are absorbed easily and quickly $[4,5]$. Another significant feature which recommends the use of pulp in the feed ration of animals is the high fiber content, $200-240 \mathrm{~g} / \mathrm{kg} \mathrm{DM}$, material of good absorption capacity and ionic exchange, thus contributing to the adjustment of the $\mathrm{Ph}$ in the digestive tract of animals, [6]. On another hand, both the beet and the pulp represent major sources of protein, $150-160 \mathrm{~g} / \mathrm{kg}$ DM, minerals: P-0.9 g/kg DM, K-4.8 g/kg DM, Na- 
$0.4 \mathrm{~g} / \mathrm{kg} \mathrm{DM}, \mathrm{Mg}-2 \mathrm{~g} / \mathrm{kg}$ DM, Ca-(9-10) g/ $\mathrm{kg}$ DM and vitamins: biotin 10-50 mg/kg DM important for animal health [7-9].

The nature and chemical structure of carbohydrates and the other compounds from the composition of sugar beet pulp allows their easy transformation into useful compounds that have a positive effect on milk production and determine an increase in fat content of 8$11 \%$ [10]. Direct metabolization of the pulp into useful compounds achieves a noticeable reduction in green-house gases $\left(\mathrm{CO}_{2}\right.$ și $\left.\mathrm{CH}_{4}\right)$ produced during digestion by the ruminants, which is a phenomenon with a positive impact on the environment. [5, 9, 11, 12].

Introduction of beet pulp or beet in animal feed is a very topical issue even if this is not a new concept. The economic efficiency of beet pulp is also due to the shorter vegetation cycle compared to that of cereals (wheat, barley etc).

The beet is a plant that adapts easily to osmotic pressure, so it can be cultivated in high alkalinity soils, which not only doesn't damage, but increases production which can reach 80 t/ha (15-17 t/ha DM) successfully replacing some cereals in the feed of ruminants and also swine [13].

Although both beet pulp and beet are highly efficient in animal feed, they cannot be stored for longer periods of time, because a higher water content determines a higher perishability. To eliminate this drawback, it is necessary to process them before storage in such a way that they will maintain their nutritional properties for longer. In practice this problem can be solved by reducing the humidity (drying) to a water content of $8-12 \%$, at which value the products do not spoil any more.

Another factor that requires drying the beet pulp with the purpose of long-term storage is given by the seasonal nature of operation of the sugar factories, from which, in comparatively short periods of time, large quantities of pulp are obtained that cannot be used completely at the time of production [14-17].

To increase the efficiency of beet pulp used in animal feed, it can be combined with macro-elements $\left(\mathrm{Ca}^{2+}, \mathrm{Mg}^{2+}, \mathrm{PO}_{4}{ }^{2+}\right)$ and micro-elements $\left(\mathrm{Co}^{2+}, \mathrm{Zn}^{2+}, \mathrm{Fe}^{2+}, \mathrm{Mn}^{2+}\right)$. For example, an addition of calcium is very important especially for high productivity milk cows which need a daily amount of 70-100 $\mathrm{g}$ of calcium, a quantity that cannot be provided only from feed [18].

It is desirable that the addition of macro-elements should be in the form of compounds that can be easily assimilated. Thus, the addition of $\mathrm{Ca}^{2+}, \mathrm{Mg}^{2+}, \mathrm{PO}_{4}{ }^{2+}$ as lime and hydrated dolomitic lime to the beet pulp before drying leads to creation of organo-mineral compounds, from which the assimilation of macro-elements is superior to carbonates. Ensuring the requirements of micro-elements $\left(\mathrm{Co}^{2+}, \mathrm{Zn}^{2+}, \mathrm{Fe}^{2+}, \mathrm{Mn}^{2+}\right)$ is achieved by adding ionic salts, respectively as sulphates $\left(\mathrm{MnSO}_{4}, \mathrm{ZnSO}_{4}, \mathrm{CoSO}_{4}, \mathrm{FeSO}_{4}\right)$.

In this paper we conducted a kinetic study of the influence of temperature and additions of lime, hydrated dolomitic lime, $\mathrm{H}_{3} \mathrm{PO}_{4}$ and micro-elements on the speed of drying. The experimental measurements taken have been used to develop a mathematical model which can be used to describe the speed of the drying process and calculate how long the material should stay in the drier when the process takes place in the temperature interval $60-95{ }^{\circ} \mathrm{C}$.

\section{Materials and methods}

The experimental study was performed with beet pulp resulted from technological process of sugar production from TEREOS-LUDUS-ROMANIA. As source for $\mathrm{Ca}^{2+}$ ions, hydrated lime obtained from industrial lime hydration was used. $\mathrm{Mg}^{2+}$ ions were added in the form of hydrated dolomitic lime prepared in laboratory by calcination at $\mathrm{t}=850{ }^{\circ} \mathrm{C}$ of the VOLŞLOBENI dolomite followed by hydration. The source for $\mathrm{PO}_{4}{ }^{3+}$ ions was phosphoric acid $\left(\mathrm{H}_{3} \mathrm{PO}_{4}\right)-85 \%$ P.A. from the supplier NORDIC-CHEMICALS CLUJ. The micro- 
elements $\mathrm{Co}^{2+}, \mathrm{Zn}^{2+}, \mathrm{Fe}^{2+}, \mathrm{Mn}^{2+}$ were added as sulphates, sulfuric acid salts of P.A. quality, from NORDIC-CHEMICALS CLUJ.

The study of drying process was carried out with the AXIS-100 moisture analyzer with $0.01 \%$ humidity accuracy and maximum working temperature $160{ }^{\circ} \mathrm{C}$, the heat input required to evaporate the moisture is achieved by means of two halogen lamps, with which the moisture analyzer is provided. Also, this analyzer has an automatic temperature control system and a software for automatic measurement at predetermined time intervals of the sample mass. The software allows the collection and storage of measured values on a PC connected to the moisture analyzer.

The samples composition is presented in Table 1.

Table 1. Composition of samples subjected to drying in relation to the dry matter

\begin{tabular}{|l|c|c|c|c|c|}
\hline \multicolumn{1}{|c|}{ Sample } & $\begin{array}{c}\text { Organic part } \\
\text { quantity [\%] }\end{array}$ & $\mathrm{CaO}$ & $\mathrm{MgO}$ & $\mathrm{P}_{2} \mathrm{O}_{5}$ & $\begin{array}{c}\text { Micro- } \\
\text { element PPP }\end{array}$ \\
\hline P0 - Raw pulp & 18.7 & - & - & - & - \\
\hline P1- Raw pulp+lime+ dolomitic lime & 65.63 & 28.5 & 5.85 & - & - \\
\hline & & & & & $\begin{array}{c}\mathrm{Co}=1.2 \\
\mathrm{Zn}=2.1 \\
\mathrm{Cu}=0.15 \\
\text { P2 - Raw pulp+lime+ dolomitic lime+ }\end{array}$ \\
$\mathrm{H}_{3} \mathrm{PO}_{4}+$ micro-elements & 61.5 & 23.2 & 5.5 & 9.8 & $\begin{array}{c}\mathrm{Fe}=1.5 \\
\mathrm{Mn}=0.25\end{array}$ \\
\hline
\end{tabular}

The influence of temperature on the drying speed of the samples was studied in the range $60-90{ }^{\circ} \mathrm{C}$ for a thin layer of material

\section{Results and discussions}

Knowing the laws according to which the complex drying process takes place allows to find the optimal solution of the engineering problems regarding the selection and sizing of the dryer and the drying process automatization. Establishing the laws that shows the evolution in time of a certain process, physical or chemical, can be done by theoretical modeling or empirical modeling

Theoretical modeling, which implies the knowledge of the kinetic equation of studied phenomenon, is difficult to achieve for the drying process due to the large number of parameters that influence the drying speed, the multitudes and complexities of the phenomena that form the global process (internal and external diffusion of water vapor, thermal transfer, etc.) as well as due to the fact that the mechanisms by which this process is carried out may change during the course.

Considering these reasons, in the case of solids drying, empirical modeling is used, that involves experimental measurements, performed under conditions similar to those of industrial practice, whose numerical values will be correlated in a kinetic equation [19-21].

Experimentally, the drying process with constant air parameters on the surface of the material is studied. The experimental values regarding the variation in time of the sample mass are processed in the form of drying curves, which reproduce the variation in time of the material moisture content.

The analysis of results, figure 1, shows the influence of the temperature on the time required for the total humidity removal, presented in table 2 .

The strong influence of temperature on the time required for total elimination of humidity is manifested for all three samples. Significant decrease, $40-44 \%$, of the time required for total removal of humidity at temperatures higher than $85^{\circ} \mathrm{C}$, especially in the case of P0 sample, is determined by the modification of the porous structure of the material. 

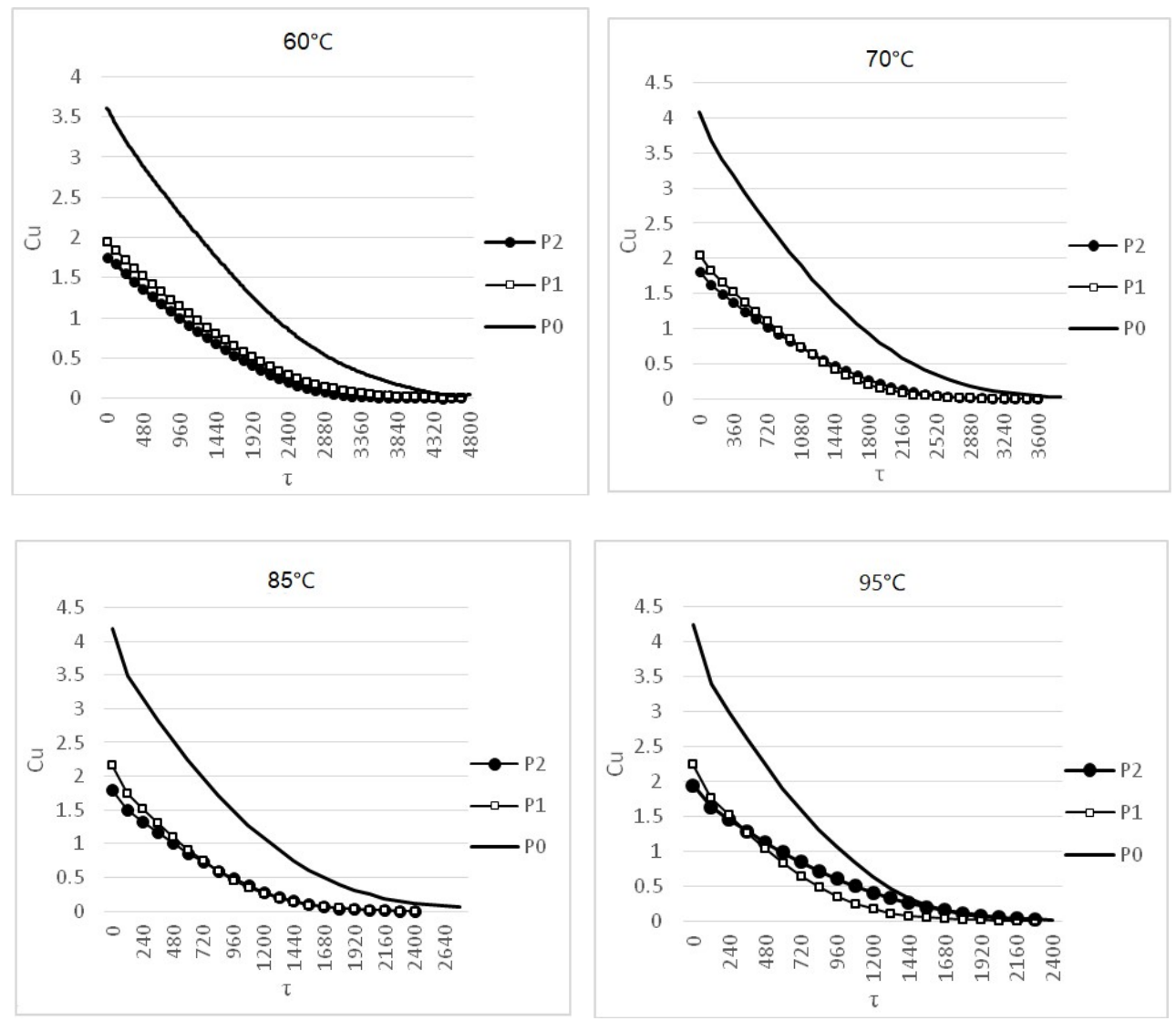

Fig.1. Variation in time of moisture content at temperatures: $60 ; 70 ; 85 ; 95^{\circ} \mathrm{C}$

Table 2. The time required for the total removal of humidity

\begin{tabular}{|c|c|c|c|c|}
\hline Temp, $\left[{ }^{\circ} \mathrm{C}\right]$ & \multicolumn{4}{|c|}{ Time [s] } \\
\cline { 2 - 5 } Samples & 60 & 70 & 85 & 95 \\
\hline P0 & 5500 & 3700 & 2800 & 2300 \\
\hline P1 & 4000 & 2650 & 2100 & 2100 \\
\hline P2 & 3600 & 2650 & 2100 & 2100 \\
\hline
\end{tabular}

At temperatures higher than $70{ }^{\circ} \mathrm{C}$ the cell walls of the pulp are broken and with this the micropores disappear, turning into macropores, in which the humidity is retained with lower forces, the desorption of vapors and diffusion through the crust towards the outer surface becoming easier. At low temperatures, the microporous structure of the pulp from which water vapor diffuses harder is maintained.

The results in Figure 1 and Table 2 show, on the other hand, the strong influence of micro- and macro-element additions. The additions, even at low temperatures, cause the pulp's cell walls to rupture, leading to a substantial reduction in the time required for total removal of humidity. In the case of the sample in which besides lime and dolomitic lime, $\mathrm{H}_{3} \mathrm{PO}_{4}$ and microelements were added, the breakdown of the cell walls and the modification of the porous structure occurred mainly at $60{ }^{\circ} \mathrm{C}$, which is why the influence of the temperature is less pronounced above this temperature threshold. 


\subsection{Mathematical modeling}

Due to the reasons stated above, theoretical modeling is difficult to approach. To describe the rate of moisture removal, the empirical models presented in Table 3 will be used.

Table 3. Equations of proposed empirical models for drying speed of a thin layer of material

\begin{tabular}{|c|c|c|}
\hline Model name & Model & References \\
\hline Newton & $M R=\exp (-k t)$ & {$[22]$} \\
\hline Page & $M R=\exp \left(-k t^{n}\right)$ & {$[22]$} \\
\hline Modified Page & $M R=\exp \left[-(k t)^{n}\right]$ & {$[22]$} \\
\hline Henderson and Pabis & $M R=a \cdot \exp (-k t)$ & {$[23]$} \\
\hline Logarithmic & $M R=a \cdot \exp (-k t)+c$ & {$[24]$} \\
\hline Two term & $M R=a \cdot \exp \left(-k_{0} t\right)+b \cdot \exp \left(-k_{t} t\right)$ & {$[25]$} \\
\hline Two term exponential & $M R=a \cdot \exp (-k \cdot t)+(1-a) \exp (-k \cdot a \cdot t)$ & {$[26]$} \\
\hline Wang and Singh & $M R=1+a t+b t^{2}$ & {$[27]$} \\
\hline
\end{tabular}
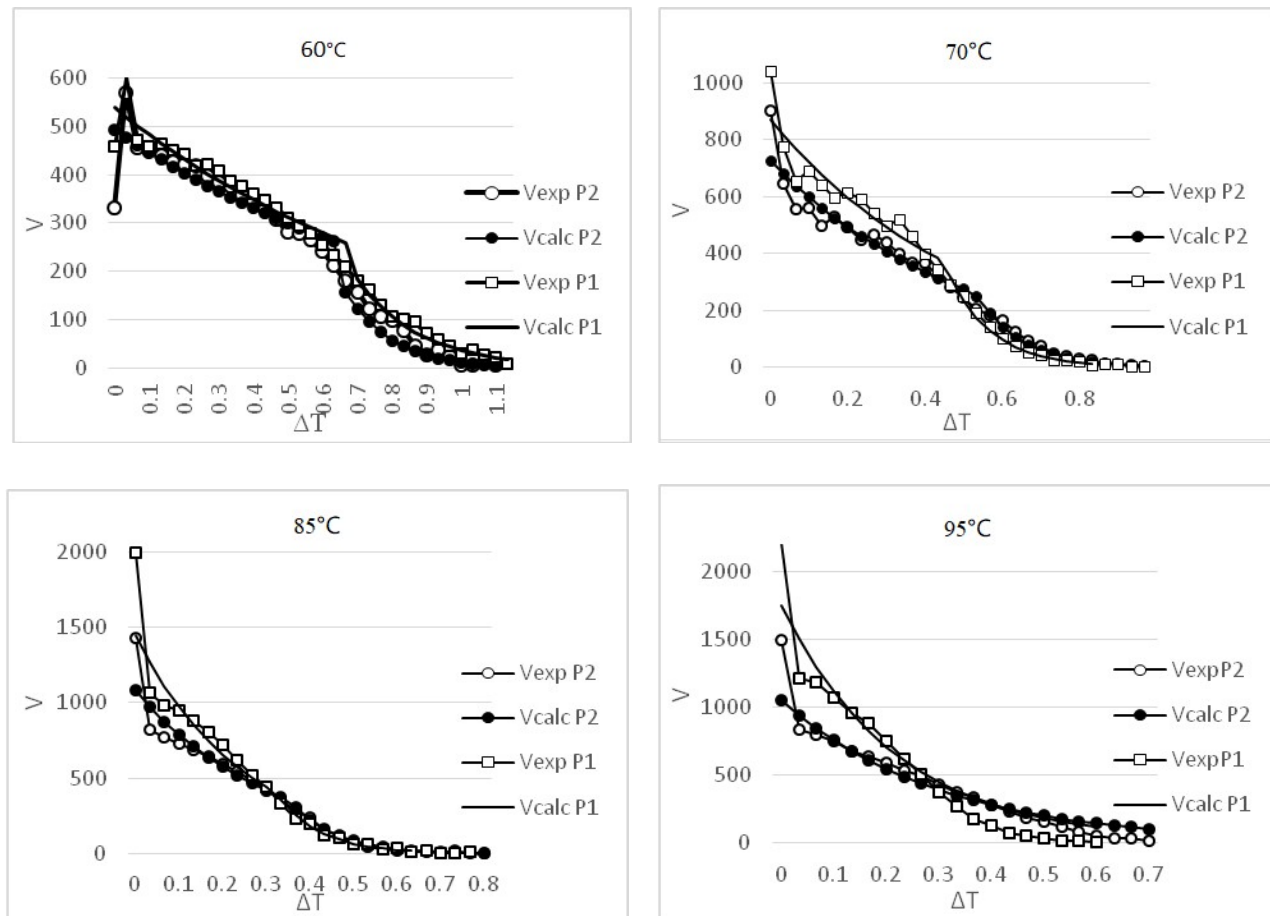

Fig. 2. Comparative values of drying speed resulted from experimental measurements with those calculated based on the proposed model

Validation of the empirical models proposed in Table 3 and their transposition into mathematical models of beet pulp drying process implies identification of the coefficients in the proposed equations.

Using the finite differences method, the experimental results, Figure 1, regarding the variation in time of humidity content were used to determine the drying speed and its variation over time.

Verification of the empirical models showed that the two-term model represents very well the experimental measurements on drying speed. 
The mathematical processing of the experimental results that shows variation in time of the drying speed led to the numerical values of the constants $\mathrm{K}$ and $\mathrm{A}$, presented in Table 4.

Table 4. Numerical values of coefficients $\mathrm{K}$ and A of the two-term model

\begin{tabular}{|c|c|c|c|c|c|}
\hline \multirow{2}{*}{ Constants } & $\begin{array}{r}\text { Sample } \\
\end{array}$ & & & & \\
& & & 70 & 85 & 95 \\
\hline \multirow{2}{*}{1} & $\mathrm{P} 1$ & 1.09 & 1.89 & 3.98 & 4.54 \\
\cline { 2 - 6 } & $\mathrm{P} 2$ & 0.977 & 1.94 & 3.16 & 3.31 \\
\hline \multirow{2}{*}{$K_{2}$} & $\mathrm{P} 1$ & 5.36 & 8.85 & 10.07 & 12.3 \\
\cline { 2 - 6 } & $\mathrm{P} 2$ & 7.45 & 8.41 & 9.81 & 10.3 \\
\hline \multirow{2}{*}{$A_{1}$} & $\mathrm{P} 1$ & 6.29 & 6.77 & 7.28 & 7.3 \\
\cline { 2 - 6 } & $\mathrm{P} 2$ & 6.21 & 6.59 & 6.98 & 6.96 \\
\hline \multirow{2}{*}{$A_{2}$} & $\mathrm{P} 1$ & 8.97 & 9.89 & 9.23 & 9.62 \\
\cline { 2 - 6 } & $\mathrm{P} 2$ & 10.03 & 10.02 & 9.33 & 9.90 \\
\hline
\end{tabular}

The verification of the proposed model by means of the constants $\mathrm{K}$ and A shows that at humidity of the material greater than $90 \%( \pm 1.5 \%)$ there is a modification of the mechanism after which the process is carried out. Thus, two zones are distinguished: the first zone which lasts for a period of time until approx. $90 \%$ of the moisture contained in the pulp is eliminated. During this period the drying process is carried out at a speed corresponding to the values $K_{l}$ and $A_{l}$ of the proposed model with the duration $\tau_{l}$. The second zone corresponds to the elimination of approx. $10 \%$ of the moisture of the pulp. This area is characterized by the $K_{2}$ and $A_{2}$ values of the proposed model and corresponding to a time duration $\tau_{2}$. The time required to eliminate the total humidity, representing the sum of the time for the both zones.

By comparing the results of the experimental measurements of the drying speed with those calculated on the basis of the proposed model (Figure 2), a good agreement is observed throughout the studied temperature range.

Determining the time required to remove the humidity at temperatures other than those at which the experimental measurements were made implies establishing the temperature dependence of $K$ coefficients of the mathematical model. The mathematical processing of the numerical values in Table 4 led to the equations in Table 5.

Table 5. Calculation equations for constants $\mathrm{K}$ and $\mathrm{A}$ as function of temperature in range $60-95{ }^{\circ} \mathrm{C}$.

\begin{tabular}{|c|c|c|c|c|}
\hline \multirow{2}{*}{ Sample } & \multicolumn{2}{|c|}{ Calc. eq.of constant $K$} & \multicolumn{2}{c|}{ Calc. eq.of constant $A$} \\
\cline { 2 - 5 } & $K_{1} \eta=0-0.9$ & $K_{2} \eta=0.9-1$ & $A_{1} \eta=0-0.9$ & $A_{2} \eta=0.9-1$ \\
\hline P1 & $K_{I}=1.09+0.098 \Delta T$ & $K_{2}=5.36+0.2 \Delta T$ & $A_{1}=6.29+0.029 \Delta T$ & $A_{2}=1.09+0.098 \Delta T$ \\
\hline P2 & $K_{I}=0.977+0.0661 \Delta T$ & $K_{2}=7.45+0.074 \Delta T$ & $A_{I}=6.21+0.0214 \Delta T$ & $A_{2}=9.82$ \\
\hline
\end{tabular}

where: $\Delta T=T_{i}-60$

$T_{i}$ - working temperature $\left[{ }^{\circ} \mathrm{C}\right]$ in the range $60-95{ }^{\circ} \mathrm{C}$

In order to establish the calculation formulas of the necessary time of stationing of the material in the dryer, so that its humidity decreases from the initial value $X_{i}$ to the final $X_{f}$, it is based on the equation that shows the moisture content of the material, $C_{u}$, depending on the degree of its removal $\eta$

where:

$$
C_{u}=\frac{M_{i}-M_{t}}{m}=\frac{X_{i}-X_{f}}{1-X_{i}}=\frac{X_{i}(A-\eta)}{1-X_{i}}
$$

$M_{i}, M_{f}$ - the initial and final humidity of the material $\left[\mathrm{kgH}_{2} \mathrm{O} / \mathrm{kg} \mathrm{DM}\right]$

$\eta$ - degree of humidity removal

$m$ - mass of dry material $[\mathrm{kg}]$

$C_{u}$ - humidity content of the material. 
By combining Equation 1 with the corresponding ones in Table 5, we obtain the relations that allow determination of the time of stationing of the material in the dryer for temperature values in the range $60-95^{\circ} \mathrm{C}$.

where: $\quad \tau_{1}=A_{1} \cdot e^{-K_{1} \tau_{1}}$

$$
\frac{X_{i}(A-\eta)}{1-X_{i}}=\tau_{1}+\tau_{2}
$$

$$
\tau_{2}=A_{2} \cdot e^{-K_{2} \tau_{2}}
$$

\section{Conclusions}

The kinetic study on drying process of beet pulp showed that the addition of $\mathrm{Ca}^{2+}$ and $\mathrm{Mg}^{2+}$ microelements in the form of lime and hydrated dolomitic lime determines the breakdown of the cell walls, modifying its porosity, which leads to a substantial increase of the speed of moisture removal.

The extra addition of $\mathrm{PO}_{4}{ }^{3+}$ in the form of $\mathrm{H}_{3} \mathrm{PO}_{4}$ and microelements $\mathrm{Co}^{2+}, \mathrm{Zn}^{2+}, \mathrm{Fe}^{2+}$, $\mathrm{Cu}^{2+}$ causes a more pronounced rupture of cell walls of the pulp at lower temperatures with a positive effect on the speed with which the drying takes place.

The results of the kinetic study carried out served to concretize the mathematical model by means of which the variation in time of the process is highlighted.

The concretization of the coefficients in the mathematical model allowed to establish the equations of calculation of the time of stationing the material in the dryer.

The equations for calculating the stationary time of the material in the dryer can be used when sizing the dryer.

This work was supported by a grant of the Romanian Education and Research Ministry through Programme 1 - Development of the national research-development system, subprogramme 1.2 Institutional performance - Projects for financing excellence in RDI, contract no. 16PFE.

\section{References}

1. M. Asadi., John Wiley\&Sons, Inc., Hoboken, New Jersey, (2007)

2. F.N. Domsa; L. Iliescu, Sugar Technology, Ed. Tehnica, Bucuresti, Romania, (1973).

3. P. Melendez; P. J Pined; J. Appl. Anim. Res, 43, 3, 261, (2015).

4. A. Lenart; J.M. Flink, Int. J. of Food Sci. \& Tech., 19 (1), 45, (2017)

5. A.P.A. Monteiro; J.K. Bernard; J.R. Guo; X.S. Weng; S. Emanuele; R. Davis, G.E. Dahl; S.Tao; J. of Dairy Sci., 100 (2), 1063, (2017).

6. A. A. M. Habeeb; A. E.Gad; A. A Taraban; I. Sanchis; L. Luján, Int. J. of Sci. Res. in Sci. and Tech., 3, 3, 107, (2017).

7. C. M Hoffman; T. Huijbregts; N. van Swaaij; R. Jansen; Eur. J. Agro., 30, 17, (2009).

8. N. Katerji; J. W. van Hoorn; A. Hamdy; M. Mastrorilli; E. Mou Karzel; Agric Water Manag. 34, 57, (1997).

9. M. Münnich; R. Khiaosaard; F. Klevenhusen; A. Hilpold; Q. Zebeli; Animal Feed Sci. and Tech., 224, 78, (2017).

10. R.E. Rauch; P.H. Robinson; L.J. Erasmus, Animal Feed Sci. and Tech., 177 (3-4), 180, (2012).

11. A. Jokić,; Z. Zavargo; N. Lukić; B. Ikonić,; J. Marković; J. Dodić; J. Grahovac; J. on Proces. and Energy in Agri., 17 (1), 24, (2013).

12. Ch.V. Boucque; B.G. Cottyn; F.X. Buysse, Livestock Prod. Sci., 5 2, 171, (1978). 
13. L. Mogensen; T. Kristensen, Acta. Agric. Scand. (A), 53, 86, (2003).

14. Q. Ertl; W. Zebeli; W. Zollitsch; W. Knaus; J Dairy Sci., 99 2, 1228, (2016)

15. E. Evans; U. Messerschmidt; J. Anim. Sci. Biotechnol., 8, 1, (2017)

16. A. A. Wahab; A. A. Salih; J Agric Sci Technol B., 2, 865, (2012)

17. L. Yang; Z. Hu; L. Yang; S. Xie; M. Yang; INMATEH - Agricultural Engineering, 55, (2), 53, (2018).

18. Z. Dancea, Nutritia animala si elemente de nutritie a omului, Ed. Tedesco, Cluj Napoca, Romania, (2005)

19. E.K. Akpinar; S. Toraman; Heat Mass Transfer, 8, 2, 110, (2015)

20. I. Doymaz; Energy Conversion and Management, 56, 199, (2012)

21. D.G. Overhults; H.E. White; H.E. Hamilton; I.J. Ross; Transactions of the ASAE, 16, 112, (1973)

22. A. El-Beltagy; G.R. Gamea; A.H. Amer Essa; J Food Eng, 78, 456, (2007)

23. S.M.Henderson; S.J. Pabis; Agricultural Eng.Res., 6(3), 169, (1969)

24. O. Yaldiz; C. Ertekin; H.B. Uzun; Energy, 26, 457, (2001)

25. I.T. Togrul; D. Pehlivan; J Food Eng, 65, 413, (2004)

26. E.K. Akpinar; Y. Bicer; Energy Convers. Manag., 49, 1367, (2008)

27. A. Kaleta; K. Górnicki; Int. J. Food Sci.Technol., 45 (5), 891, (2010) 